\title{
THE EFFECTS OF FOOT BINDING CUSTOM IN LISA SEE'S NOVEL SNOW FLOWER AND THE SECRET FAN
}

\author{
Moh. Gusnaldi Putra and M. Manugeren \\ Faculty of literature, Universitas Islam Sumatera Utara, Medan, Indonesia \\ e-mail: m.gusnaldi.p@gmail.com
}

Received: 25 Maret 2019

Accepted: 20 July 2019

\begin{abstract}
This study constitutes an Analysis of The Effect of Foot Binding Custom from Lisa See's novel Snow Flower and The Secret Fan published in 2006. The Positive and Negative effects are the topics to discuss. This analysis uses the data taken from the novel applying descriptive qualitative research. One of the significant theories of the custom used in this study is that a person who claims that the essence of a culture having a custom in it is not its artifacts, tools, or other tangible cultural elements but how the members of the group interpret, use, and perceive them. It is the values, symbols, interpretations, and perspectives that distinguish one from another in modernized societies; it is not material objects and other tangible aspects of human societies. People within a culture usually interpret the meaning of symbols, artifacts, and behaviors in the same or in similar ways. The findings show that Foot Binding Custom gives women positive effects such as high statue in the society, and symbol of beauty. Besides the positive effects, there are also negative effects such as infection, and even death. The conclusions of the study are Foot binding, as the time goes by, is not persevered anymore as it gives more negative effects than the positive ones. However, health is the most important part of human life. Health is the pivot upon which a man's whole personality and its wellbeing depend. An ailing and aching body saps the enthusiasm for pursuit. Unwholesome feelings and sensations retard the pace of functional activity, economic development and spiritual uplift.
\end{abstract}

Keywords: culture, custom, foot binding, modernism, beauty

\section{Introduction}

The novel entitled Snow Flower and The Secret Fan written by Lisa See is a novel about love, a delicate story of two women in nineteenth-century China, who pledge themselves to be soul-mates for life at the young age of seven. Although the truth is stretched to accommodate the relationship, they are supposed to have seven "characters" that match; the girls are born in the same month and have their feet bound at the same age, but it turns out that there are differences between them discovered when adults. Binding their lives is their continuous learning of women's writing called "nu shu" which is a secret, a minimalist variation of "men's" writing, and one which can only be known by female. 
The culture of Hunan during this period of history was dictated by very strict rules and customs, including that of binding the feet of young girls before they entered puberty. After the binding, girls were restricted to the women's upstairs parlor, where they would remain, primarily, throughout their lives. Only as young children in their "milk years" were they allowed to see the outside world and to explore nature. Their lives were devoted to creating embroidered clothing and quilts and building their wardrobes and those of their future husbands to create a dowry. Women were considered "worthless branches" in the family tree, and their sole purpose was to produce sons for their husbands. Since feeding a family was a major challenge, a female mouth to feed was simply a liability.

Foot binding (known as Lotus feet) is the custom of applying painfully tight binding to the feet of young girls to prevent further growth. The practice was possibly originated among upper-class during the five dynasties and ten kingdoms in imperial China $\left(10^{\text {th }}\right.$ or $11^{\text {th }}$ century). Foot binding became popular as a means of displaying status (women from wealthy families who did not need them to work could afford to have their feet bound) and was correspondingly adopted as a symbol of beauty in China culture.

Besides, the goal of this custom is to achieve a pair of perfectly bound feet with seven distinct attributes: they should be small, narrow, straight, pointed, and arched, yet still fragrant and soft in texture. Of these requirements, length is not more important. A perfect foot should be shaped like the bud of a lotus. It should be full and round at the heel, come to a point at the front, with all weight born by the big toe alone. This means that the toes and arch of the foot must be broken and bent under to meet the heel. Finally, the cleft formed by the forefoot and heel should be deep enough to hide a large cash piece perpendicularly within its folds.

All the various circumstances which emerge in this world can be explained through the law of cause and effect. Where there is no cause, there can be no effect. Effects are produced precisely because there are causes. The law of cause and effect is widely known and commonly accepted in today's world. Effect in this study will be related to foot binding custom in the novel Snow Flower and the Secret Fan by Lisa See. Thus, there will be two effects. They are positive effect and negative effect of foot binding custom in this novel.

In all, this novel tells us about women's life in foot binding custom. This custom is a parameter to man to get marriage. According to Chinese custom, a woman with a small foot will have the greatest love and joy in her life. Therefore, this novel can be as a means to expose how the custom is, what effects are given to the followers of the custom, and whether this custom gives good effects to the people.

The effects of Foot Binding Custom in Lisa See's novel Snow Flower and The Secret Fan is very interesting to analyze because the topic discusses the effects of foot binding which are useful for the readers.

\section{Literature Review}

Culture is defined as the shared patterns of behaviors and interactions, cognitive constructs, and affective understanding that are learned through a process of socialization. These shared patterns identify the members of a culture group while also distinguishing those of another group.

In Multicultural Education, Banks and McGee (1989: 1) explains,

"Most social scientists today view culture as consisting primarily of the symbolic, ideational, and intangible aspects of human societies. The essence of a culture having a custom in it is not its artifacts, tools, or 
other tangible cultural elements but how the members of the group interpret, use, and perceive them. It is the values, symbols, interpretations and perspectives that distinguish one people from another in modernized societies; it is not material objects and other tangible aspects of human societies. People within a culture usually interpret the meaning of symbols, artifacts, and behaviors in the same or in similar ways."

Custom is a usage or practice common to many or to a particular place or class or habitual with an individual. For example, it is the custom for the bride to wear a whitedress on her wedding day. Then, habit is often referred to a regular behavior that is recurrently repeated. Moreover, a habit is also considered to subconsciously happen. The person showing habitual behavior is often unaware of his actions. This is due to the reason that a person performing routine tasks will not bring himself to take on self-analysis.

A tradition is a belief or behavior passed down within a group or society with symbolic meaning or special significance with origins in the past.Common examples include holidays or impractical socially meaningful clothes (like lawyer wigs or military officer spurs), but the idea has also been applied to social norms such as greetings. Traditions can persist and evolve for thousands of years - the word "tradition" itself derives from the Latin tradere or traderer literally meaning to transmit, to hand over, to give for safekeeping.

Foot binding (known as "Lotus feet") is the custom of applying painfully tight binding to the feet of young girls to prevent further growth. Suffering for beauty is a concept familiar to most women, who have die, plucked or shaved their hair, squeezed their feet into uncomfortable high heels or even surgically enhanced parts of their anatomy. Millions of Chinese women went even further - binding their feet to turn them into the prized "three-inch golden lotuses." The procedure for Foot Binding generally involved tightly wrapping a strip of cloth that is similar to a bandage around the smallest toes and the rest of the foot. The big toes were likely to be the only parts of the foot that were free. The cloth was tightened daily to make the foot more slender and shorter. This process eventually broke the toes, and the tight binding raised the arches of the girls' feet. Other definition of Foot Binding is a practice of wrapping the foot in cloth to form its shape and size into that which is socially deemed beautiful or fashionable. The practice involves forcing all the toes bit the big toe under the sole of the foot with cloth bandages, stunting the foot's growth and increasing the arch. (Emily Laurel Smith, 2008: 201-202) Foot Binding was first banned in 1912, but some continued binding their feet in secret. Some of the last survivors of this barbaric practice are still living in Liuyicun, a village in Southern China's Yunnan province. Wealthy Chinese women with bound feet pose for a photo, circa 1900-1920.

Legend has it that the origins of foot binding go back as far as the Shang dynasty (1700-1027 B.C.). The Shang Empress had a clubfoot, so she demanded that foot binding be made compulsory in the court. But, historical records from the Song dynasty (9601279 A.D.) date foot binding as beginning during the reign of $\mathrm{Li} \mathrm{Yu}$, who ruled over one region of China between 961-975. It is said his heart was captured by a concubine, Yao Niang, a talented dancer who bound her feet to suggest the shape of a new moon and performed a "lotus dance."

During subsequent dynasties, foot binding became more popular and spread from court circles to the wealthy. Eventually, it moved from the cities to the countryside, where 
young girls realized that binding their feet could be their passport to social mobility and increased wealth.

Prestige refers to the reputation or esteem associated with one's position in society. A person can earn prestige by his or her own achievements, which is known as achieved status, or they can be placed in the stratification system by their inherited position, which is called ascribed status. For example, prestige used to be associated with one's family name (ascribed status), but for most people in developed countries, prestige is now generally tied to one's occupation (achieved status). Occupations like physicians or lawyers tend to have more prestige associated with them than occupations like bartender or janitor. An individual's prestige is closely tied to their social class - the higher the prestige of an individual (through their occupation or sometimes, their family name), the higher their social class.

Prestige is often related to the other two indicators of social class - property and power. A Supreme Court justice, for example, is usually wealthy, enjoys a great deal of prestige, and exercises significant power. In some cases, however, a person ranks differently on these indicators, such as funeral directors. Their prestige is fairly low, but most have higher incomes than college professors, who are among the most educated people in America and have high prestige.

Prestige is a strong element in social mobility. On the one hand, choosing certain occupations or attending certain schools can influence a person's level of prestige. While these opportunities are not equally available to everyone, one's choices can, at least to a limited extent, increase or decrease one's prestige, and lead to social mobility. On the other hand, certain elements of prestige are fixed; family name, place of birth, parents' occupations, etc., are unchangeable parts of prestige that cause social stratification. (Boundless Sociology, 2014: 1)

The definition of beauty, which in the terms of successive analysis and narrowing of the conception is value positive, intrinsic, and objectified. In less technical language, Beauty is pleasure regarded as the quality of a thing. Beauty is a value, that is, it is not a perception of a matter of fact or of a relation: it is an emotion, an affection of our volitional and appreciative nature. An object cannot be beautiful if it can give pleasure to nobody: a beauty to which all men were forever indifferent is a contradiction in terms.

... Beauty is therefore a positive value that is intrinsic; it is a pleasure.

(Santayana, 1995: 50-51)

It is worth saying that Santayana's treatment of the topic in The Sense of Beauty (1896) was the last major account offered in English for some time, possibly because, once beauty has been admitted to be entirely subjective, much less when it is held to rest on a sort of mistake, there seems little more to be said. What stuck one's treatments was the subjectivity, not the heroic attempts to temper it. If beauty is a subjective pleasure, it would seem to have no higher status than anything that entertains, amuses, or distracts; it seems odd or ridiculous to regard it as being comparable in importance to truth or justice, for example. And the twentieth century also abandoned beauty as the dominant goal of the arts, again possibly in part because its trivialization in theory led artists to believe that they ought to pursue more real and more serious projects.

Wounds are injuries that break the skin or other body tissues. They include cuts, scrapes, scratches, and punctured skin. They often happen because of an accident, but surgery, sutures, and stitches also cause wounds. Minor wounds usually are not serious, but it is important to 
clean them. Serious and infected wounds may require first aid followed by a visit to your doctor. You should also seek attention if the wound is deep, you cannot close it yourself, you cannot stop the bleeding or get the dirt out, or it does not heal. (Medlineplus, 2014: 1)

Good health starts from the very infancy. It is here that protection and care is needed, so that each organ functions well, each organ develops naturally, and there are no deformities, disabilities and diseases but often the health of children remain neglected, with the result that they grow unhealthily and that affects their education as well. Health cannot be achieved merely by taking one or two pills every day or by observing a few restrictions. It can be achieved only by understanding what health is, on what it depends and then applying this knowledge in every-day life. The care of the body regarding food, cleanliness, exercise, rest and protection against disease, are essential for the preservation of sound health. Life is for living. Without health, life is deprived of not only much of its usefulness but also its joys and pleasures. The stream of life will be rich and lasting in proportion to the sources which nourish it. These sources belong to every person. They are food, exercise, and proper posture, care of bodily functions, avoidance of alcohol and tobacco, and wholesome mental and emotional attitudes.

\section{Research Method}

Research designs are plans and the procedures for research that span the decisions from broad assumptions to detail methods of data collection and analysis (Creswell, 2009: 3 ). This research uses qualitative descriptive method which explores and understands the social or human phenomenon reflected in the novel. Intrepretation of the data elaborate in Discussion session to make the meaning of the data clear.

\section{Discussion}

In this research, the analysis is focused on the data available in the novel Snow Flower and the Secret Fan by Lisa See. The data taken from the novel are mostly about the effects of foot binding custom discussed in this research; foot binding custom, social prestige, symbol of beauty, and value of health. Then, the effects of foot binding custom are analyzed with reference to the modern theories of custom. Therefore, the sayings of many contemporary custom experts are found in this research. The sayings are taken from many different sources.

Foot binding (known as Lotus feet) is the practice of wrapping the foot in cloth to form its shape and size into that which is socially deemed beautiful or fashionable. The practice involves forcing all the toes bit the big toe under the sole of the foot with cloth bandages, stunting the foot's growth and increasing the arch. This practice was possibly originated among upper-class during the five dynasties and ten kingdoms in imperial China $\left(10^{\text {th }}\right.$ or $11^{\text {th }}$ century). Foot binding became popular as a means of displaying status (women from wealthy families who did not need them to work could afford to have their feet bound) and was correspondingly adopted as a symbol of beauty in China culture.

Besides, the goal of this custom is to achieve a pair of perfectly bound feet with seven distinct attributes: they should be small, narrow, straight, pointed, and arched, yet still fragrant and soft in texture. These requirements, length is not more important. A perfect foot should be shaped like the bud of a lotus. It should be full and round at the heel, coming to a point at the front, with all weight born by the big toe alone. This means that the toes and arch of the foot must be broken and bent under to meet the heel. Finally, 
the cleft formed by the forefoot and heel should be deep enough to hide a large cash piece perpendicularly within its folds

The foot-binding ritual traditionally begins with the clipping of the toenails and the soaking of the feet either in hot water or in a concoction of ingredients ranging from various herbs and nuts to less desirable substances such as urine and warm animal blood. This is allegedly to soften the tissue and bones of the foot to facilitate manipulation. After the feet are massaged and doused with alum. All the toes on the foot, save for the big one, are broken and folded under the sole, and then the toes are bound in place with a 10'x2" silk or cotton bandage These wrappings are removed every two days to allow the washing and meticulous manicuring of the toenails to avoid infection. This is no act of kindness immediately after this pedicure, the bandages go back on and tighter. Eventually the arch of the foot is also broken and the foot is pulled straight with the leg. The process of Foot Binding Custom seen in the following:

Mama washed my feet and rubbed them with alum, to contract the tissue and limit the inevitable secrettations of blood and pus. She cut my toenails as short as possible. During this time, my bandages were soaked, so that when they dried on my skin, they would thighten even more. Next, Mama took one of endof bandage, placed it on my instep, then pulled it over my four smallest toes to begin the process of rolling them underneath my foot. From here she wrapped the bandage back around my heel. Another loop around the ankle helped to secure and stabilize the first two loops. The idea was to get my toes and heel to meet.,creating the cleft,but leaving my big toe to walk on. Mama repeated this steps until the entire bandage was used. Finally, Mama sewed the end tightly shut so the bindings would not loosen and I would not be able to work my foot free. (Lisa See, 2006: 32)

The quotation above shows how the process of Foot Binding custom is done. Lily is one of the main characters who bind her feet with this process. Though her feet are broken, she does not mind for the sake of getting a better life in future.

\subsection{The Positive Effects of Foot Binding Custom Social Prestige}

Prestige refers to the reputation or esteem associated with one's position in society. A person can earn prestige by his or her own achievements, which is known as achieved status, or they can be placed in the stratification system by their inherited position, which is called ascribed status. Prestige is usually used to be associated with one's family name (ascribed status), but for most people in developed countries, prestige is now generally tied to one's occupation (achieved status).

Pertaining to this custom, any woman who has done foot binding will surely get a prestige in the society and generally life will be better off. This is seen in the following quotation:

"A high family will bring you better connections, a better bride-price, and long-term political and economic protection. Though I appreciate the hospitality and generosity that you have shown today,"she said, emphasizing the meagerness of our home with a languid movement of her hand, "fate-in the form of your daughter- has brought you an opportunity. (Lisa See, 2006: 25) 
The process of Foot Binding shows that the followers of this custom will get a high statue when the process is perfect. Then the family of this custom followers will get a great opportunity when their daughter gets golden lotus feet, and a good husband.

\section{Symbol of Beauty}

In this novel, the concepts of beauty is seen in the society if only the women make a binding to their feet. It is described in this quotation:

And, though I knew nothing of this at the time, my feet would be something that would hold my husband's fascination during the most private and intimate moments between a man and a women. His desire to see them and hold them in his hands never diminished during our live together. (Lisa See, 2006: 43- 44)

From the quotation, it is shown that the man will get a certain fascination to a woman who has small feet (golden lotus). So the foot Binding gives a positive effect, that is a symbol of beauty.

\subsection{The Negative Effect of Foot Binding Custom}

Apperently, foot binding custom can cause injury on the feet of its practitioners. The injured feet may also get infection due to the binding.

Mama scrubbed at those feet, trying to remove the infection. Third sister fainted. The water in the bucket became murky with noxious discharge. Finally mama pulled the broken appendages from the bucket and patted them dry. (Lisa See, $2006: 40$ )

In the quotation above, it is shown that the negative effect of foot Binding is the cause the infection of the feet of the followers of this custom. Futhermore, it can also cause the death. It is described in the quotation:

Baba went out into the storm and brought back the village doctor, who looked at third sister and shook his head. It was a first time I saw that gesture, which means that we are powerless to stop the soul of a loved one from leaving for the spirit world. (Lisa See, 2006: 41)

It is described that when the process is not perfect, it may cause injury or even death.

After the effects of Foot Binding Custom are analysed in the novel Snow Flower and the Secret Fan, some findings can be stated as the following:

1. Foot Binding Custom makes the women in this custom get many positive effects, such as: high statue in the society and symbol of beauty.

2. Beside the positive effects, there is also one significant negative effect that is injury. This injury may cause irritation and infection and if this is not well treated, it may cause death.

\section{Conclusion}

After the effects of Foot Binding Custom in the novel Snow Flower and the Secret Fan by Lisa See are analysed, some conclusions can be drawn as the following.

1. Foot binding is a custom that is used by women in China.

2. Foot binding may cause positive and negative effects to the followers of this custom.

3. Foot binding custom makes the women in this custom get positive effects, such as: high statue in the society, and symbol of beauty. 
4. Beside the positive effects, there is also negative effect. The negative effect is clearly seen in the form of infection on the feet, which may disturb health.

5. Foot binding, as the time goes by, is not persevered anymore as it gives more negative effects than the positive ones.

\section{References}

Banks, J.A., \& McGee, C.A. (1989). Multicultural Education. Needham Heights, Massachusetts: Allyn \& Bacon.

Creswell, Jhon W. (2009). Research design, qualitative, quantitative, and mixed methods Approaches. Calofornia: Sage.

Santayana, George. (1995). The Sense of Beauty: Being the Outline of Aesthetic Theory. London: Dover Publication.

See, Lisa. (2005). Snow Flower and Secret Fan. New York: Random House Inc.

See, Lisa. (2006). Snow Flower. Bandung: Qanita.

Smith, Emily Laurel. (2008). Cultural Encyclopedia of the Body. London: Green Wood Press London.

. (2014). Social Prestige. https://www.boundless.com/sociology/textbooks/ boundless-sociology-textbook/ (May, 2015).

(2014). Wounds and Injuries. http://www.nlm.nih.gov/medlineplus/ woundsandinjuries.html (May, 2015). 